\title{
Rabson-Mendenhall Syndrome
}

National Cancer Institute

\section{Source}

National Cancer Institute. Rabson-Mendenhall Syndrome. NCI Thesaurus. Code C131000.

An autosomal recessive condition caused by mutation(s) in the INSR gene, encoding the insulin receptor, and characterized by insulin resistance, intrauterine growth restriction (IUGR) and/or failure to thrive, muscle atrophy, hypertrichosis, and distinctive facial features; the condition is typically diagnosed early in life, with death usually occurring before the third decade of life. The symptoms and course of this syndrome are moderately severe as compared to the other two syndromes on the spectrum: Insulin Resistant Diabetes Mellitus with Acanthosis Nigricans and Hyperandrogenism, and Donohoe Syndrome. 